\title{
Using Cultural Capital for Urban Management, Khon Kaen Municipality, Thailand ${ }^{1}$
}

\author{
By Kanta Vilachai*
}

\begin{abstract}
Creative economy development is an invaluable way to develop Thailand economy, moreover, the cultural capital development is also the important tool to develop creative economy. This qualitative research aimed to evaluate the cultural capital application in the members of KhonKaen municipal council and others for the urban management. The data were collected by using the participatory observation and in-depth interview.

The results show that 1) "Isan wooden buddha statues", a cultural capital in Isan region, have been used as "tool" of urban management which encouraged by members of KhonKaen municipal council and 2) KhonKaen municipality applied "Isan wooden buddha statues" as a "tool" and "issue" in KhonKaen urban management affairs.

In conclusion, this provides an opportunity for promote people participation to conduct a new kind of related to creative the sustainable urban developmentor put the cultural content as a part of the social bonds strategies.
\end{abstract}

Keywords: Urban Management/ Cultural Capital Management/ Sustainable Development

\section{Introduction}

Khon Kean Municipality is a large city of Thailand, located in the northeastern region. Due to the development trends identified in the National Economic and Social Development Plans, the city has been enhanced as a growth pole of northeastern region. As a result of this trend, the city has played significant roles for being a regional core of economic, commercial, investment, transportation, medical hub and education. In 2014, the government promoted this city to be a center for Meetings, Incentives, Conferences, and Events (MICE), called Khon Kaen MICE city. Another point based on its geographical location, the city gained development opportunities as a result of East-West Economic Corridor Economic Development Policy. Another beneficial point, it is located near the Inland Container Depot (ICD) of the region, in Ta Pha District, approximate by 12 kilometer. According to all advantages, it has recently selected to be a transport hub, under rail development plans of the country.

According to all development trends, the city has rapidly grown and be urbanization by having more population including both registered and unregistered, living in this city. Many economic activities have been created owning to the growth. Therefore, the city has encountered with many impacts and needs a well-organized of administration and

${ }^{1}$ This paper is a part of the research project, The Role of Municipality Council Members in Khon Kaen Municipality Administrative Affair, were funded by College of Politics and Governance, Mahasarakham Univerity in fiscal year 2015. 
management, in order to promote a good quality of life and retain traditional way of living and its cultures. All of these points bring a crucial challenge to the city municipality.

The Khon Kaen City Municipality (KKCM) is a core unit providing administrative works and management for the city. The municipal government contains of the executive branch, led by the mayor and vice mayors and the legislative branch, led by the Council of KKCM. The municipality has gained well management under the administration done by the "Rak Pattana Nakorn Khon Kaen Team". Rak Pattana Nakorn Khon Kaen (RPNKK) has obtained majority votes from many elections for more than 20 years in leading the management of KKCM. Based on their management, this city municipality has developed well and been awarded from the well-known prize given for the best local government administration, from King

Considering the movement of the administrative and management of KKCM, it becomes an interesting point for this study to learn more from its success. Especially, this study will focus more on the aspect of using 'the cultural capital' as an approach to lead a sustainable development of the city. It will emphasize to find out about the administrative roles of the municipal council committee in creating a social bond which will influence a direction of the development of the city in sustainable way.

\section{Objectives}

1) To investigate the good practices in using the cultural capitals for the administrative and management of $\mathrm{KKCM}$

2) To explore the roles and influences of the municipal council committee and relevant agencies promoting the use of the cultural capitals for the administrative and management of KKCM

\section{Scope and Research Methodology}

This study is a qualitative research which will document the data and success stories through using participatory action research approach. It will be done through applying several methods for data collection and analysis as listed below.

1) The secondary data collection will be done through a literature review and case studies review

2) Primary data collection will be also employed. An in-depth interview with a semistructure questionnaires developed will be a key tool for gathering these data. The sample selected as the target groups for interview are the eight committee members of the municipal council committee, the municipal government of KKCM which include the mayor, the four vice mayors, the two government officials; two of the northeastern cultural experts and six local leaders

3) Participant observation will be needed for data collection process, especially participating and attending in the cultural activities and urban development events 


\section{Research Framework}

The urban planning theories and the urban growth concept are defined as a key foundation in conducting this study. These key theories will help to predict a vision of city development and a trend of the growth of the city. This study will also adopt a concept on government by network to analyze the roles and influence of the municipal governor team and the council committee contributing and leading a success of a development and management of the city, with supports from all relevant stakeholders including local government agencies, private sectors and civil society organizations. Importantly, this study will emphasize on how the innovation of city administration is created based on the use of the cultural capitals. It will especially take a consideration at the roles and involvement of the KKCM's council committee members to initiating the kind of this capital as the innovative management for their city development.

\section{Result of the Study}

The results of this study can be described in brief as follows;

1) The executive branch and legislative branch of KKCM; especially the council, have taken a cooperation together to identify and formulate the policy framework for KKCM development. Their administrative works and movement have been based on a trust and respect in local people voices and opinions, so as to drive the development of KKCM to meet a universal trend. To generate this perspective, they have set a clear of city development vision which is "The KKCM's development is intended to be universal by at the same time increasing happiness in its society". There are four city development strategies which are;

- KKCM aims to increase a capacity of its institution in initiating the administrative works and management based on participatory process. The city municipal emphasizes to empower and build capabilities of their human resources, to decentralize its power and to strengthen capacity of local people participating in the management and development of the city.

- KKCM will be developed based potential gained. For example, it will be prepared well to be a central of economic hub, to enhance green city perspective and to promote tourism. It also supports a discipline in all developments of the city and its society.

- KKCM will increase its potential to be the central service spots such as medical hub, MICE city and Event city

- KKCM will intend to create a better life for their people such as enhancing a preservation of natural resources management and a good quality of environment; improving a quality of life; promoting a harmonized society and developing education; and maintain local traditional and cultures and religions.

2) The council committee members have played important roles and influenced to initiating the use of cultural capital to lead a participatory development and management of the city. "Wooden Buddha statue" is the one key of cultural capital used for this initiative. The wooden Buddha statue is a significant and has a meaningful in the northeastern culture. Therefore, the wooden Buddha image was chosen as a traditional tool used for the administrative management of KKCM. This initiative was first created 
by Mr. Ruangchai Trachoo, the chairman of the council committee of KKCM. Mr. Trachoo was participated as the council member since 1957 and then was elected as the mayor from 1983 to 1990 . In 2014, he and the other members enhanced a trend of wooden Buddha statue making which this was developed as a kind of socio-cultural project of the city. This project was done by 2015 and it can create the product of wooden Buddha statues up to 84,000 pieces which the numbers are the same with the numbers of the doctrine topics taught by the lord of Buddha. Particularly, the numbers have another significant for the city, which KKCM has entered to its years of $80^{\text {th }}$ in this 2015.

The reasons in making the wooden Buddha statues given by the council committee members are interesting. Base on the beliefs inherited by the northeastern people, the wooden Buddha statues would be made by the local people, not by a craftsperson. The local people would use wooden raw materials which can be found in their areas for making the statues. The wooden Buddha would be built in a simple way but have great meaningful in a Buddhism belief. In long period of time, the wooden Buddha statues were the handmade crafts. To produce one of statue, it needs to take time and a concentration on craving the neat and beautiful statue. So, one wooden Buddha built would be only very unique. Some people could achieve in creating it but some are not and fail along the way. Time to pay attention to this making process could taught people to keep be patient, have a mindfulness in doing things and see all uncertainty could be happened - which all of these follow the same principles of some the doctrines taught by the lord Buddha.

In addition, the wooden Buddha statue making has been declined in the present and far from recognition of new generation. Therefore, the group of council committee members has been willing to find some tool to incentivize a participation of local people in doing things together. The wooden Buddha statue was defined by a key tool in harmonizing and building a participation of local to perform activities together. This kind of strategy is such a smart initiative to be used to gathering people in doing things well together. It creates a trend and the issue for the society which can be utilized as the activity to drive a unity for city development. It could also promote retention of culture which could be transferred from generation to generation in the future.

3) KKCM and the council committee members do not only focus on the end products of wooden Buddha statue making, but they also give important to the processes in making these. For instance, the team searched for the local cultural experts and traditional craftsperson and appointed them as the resources persons to transfer the knowledge of statue making to others. The team created and promoted the special courses of wooden Buddha statue making in the local communities and school, in order to spread this cultural aspect widely. At the end, it was not just the activity of making the statue but it is a mechanism in creating networks for a knowledge transfer in the society of the municipality area. The activities created through these courses and learning processes enhanced the chances for local people to interact and exchange their ideas, vision, and experiences required in the development of the city. This is such a great way to create a participatory platform for local to talk, meet, share and reflect their voices to each other and finally, the voices can be gathered and be as the inputs for improving the policy and development trend of the city. 
All wooden Buddha statue products made through this project have been used as a thank you present of the municipality to giving to the honor people which involved in the development processes of the KKCM and using as the valuable presents for its $80^{\text {th }}$ anniversary year. Some of these products were sold as income generation for the education fund and scholarship for the local outstanding students living in the KKCM area. Through this study, it found that this project can bring participation of many local communities in the area. There are 95 communities joined in this project. It was also gained a well reputation and supports of the private sector in the KKCM area, Khon Kaen Province and others. The project was also create tourist activity based on this statue making activities in order to promote the local culture and learning to public and it could generate income from tourism to the city as well. It could be seen that using the cultural capital, such as the wooden Buddha statue making, can raise more dynamic resulting in and leading to the development of the city in different angles.

\section{Conclusion}

Utilizing the cultural capital led in city development of the KKCM brought very several advantages for the development of the city. It is because of the leaders of municipal government have had a long term vision and understand well the cultural context including how to benefit from them for their city development activities. This project promoted learning processes among city society as well as self-learning to maintain the local belief. Then at the same time, it built networks of local people participating in this project. At the end, they can find turning point to use this cultural capital to build a platform and to unite local people to join, exchange and reflect their needs for the future development of the city. This initiative followed the principle of H.M the king, which said about "to first understand the contexts, then reach out and finally create the developments" Therefore, this would generate the learning process along the way of the development and by the end sustainable development would be generated.

\section{Reference}

Bogason, Peter.(2000) Public Policy and Local Governance: Institutions in postmodern society. Cheltenham, U.K.: Edward Elder.

Dryzek, John S. (2010). Foundations and Frontiers of Deliberative Governance. Oxford: Oxford University Press.

Dye, Thomas R. (2002). Understanding public policy. Upper Saddle River, N.J.: Prentice-Hall.

Eisenschitz, Aran and Gough, Jamie.(1993) The Politics of Local Economic Policy: The Problems and Possibilities of Local Initiative. London: The Macmillan Press.

KhonKaen Municipality. (2016). Nam Boon Sai Jai Salak Mai KhamKoon. Thailand: Prathammakhan Press. Kraft, Michael E. and Furlong, Scott R. (2007). Public policy: Politics, analysis and alternatives. Washinton, D.C.: Press.

Niyom Wongphongkham. (2002). Wooden buddha in I-San. Thailand: : Siriphan.

Hajer, Maarten A.and Wagenaar, Hendrik. (2009). Deliberative Policy Analysis : Understanding Governance in the Network Society. Cambridge : Cambridge University Press.

Taylor, Marilyn. (2003). Public Policy in the Community. New York: Palgrave Macmillan. 
Torfing, Jacob, Peters, B. Guy, Pierre, Jon... [et al.]. (2012). Interactive governance: advancing the paradigm. Oxford: Oxford University Press. 